\title{
Flood Risk Assessment and Mitigation Strategy - Taunsa Barrage Wildlife Sanctuary, Kot Mithan - Chachran, Indus Dolphin Reserve
}

\author{
Irfan Ashraf ${ }^{1}$, Sajid Rashid Ahmad ${ }^{1}$, Uzma Ashraf ${ }^{2 *}$ \\ ${ }^{1}$ College of Earth and Environmental Sciences, University of the Punjab, Lahore, 54000, Pakistan \\ ${ }^{2}$ Department of Environmental Science and Policy, Lahore School of Economics, 55000, Pakistan
}

Received: 21 January 2021

Accepted: 12 May 2021

\begin{abstract}
Flood risk management comprises two phases; the first deals with risk analysis and assessment while the second considers risk prevention and mitigation. Geographic Information System (GIS) and Remote Sensing (RS) based multi-thematic scenario is developed, risk extent and quantity were calculated at multiple levels. Taunsa Barrage Wildlife Sanctuary was selected as study area. Assets at risk were estimated in numbers showing annual average damage per unit area and coverage maps show their distribution pattern. Risk zonation layers were also developed to estimate the risk extent in terms of high, medium, and low risk. Population data were acquired and analyzed to find out inhabitants at different risk categories. Similarly, erosion and accretion layers were extracted from temporal land cover/land use datasets to analyze environmental risk. Results of flood inundation were utilized for flood depth analysis. During the 2010 Flood, almost 4200 small and large villages/towns were inundated. Out of 4,200, approximately 1,750 villages/towns are on the right bank and the remaining 2,450 are on the left bank which highlights high economic and financial risk. However, all methods chosen here to estimate the different risk criteria (inundation modeling as well as damage evaluation) are approximate approaches but develop a strong foundation for decision-makers.
\end{abstract}

Keywords: multi-thematic flood risk, inundation modeling, mitigation, risk, treatment

\section{Introduction}

Pakistan suffers from floods in main rivers of Indus River system due to disturbed weather patterns during monsoon in addition to snowmelt $[1,2]$. In lower reaches of Indus River system (Southern \& Western Punjab and Sindh), river flooding causes more damage

*e-mail: ozmaashraf@gmail.com due to longer inundation period and its coverage area over fluvial plains in contrast to northern hilly terrains [3]. Although artificial flood prevention structures like protection bunds at river embankments are built in southern Punjab and Sindh areas, due to poor maintenance, they are easily breached causing heavy damage to areas lying in river plain [4,5]. This causes flash flooding in northern areas due to steep catchments [6]. Whereas fluvial flooding, which is a slowly rising water level, occurs in region of the Central Indus Wetlands Complex (CIWC) and can be predicted by 
identifying the extent and profile of the floodplain [7]. Internal political setup also causes severe inundation when the protection bund is intentionally broken under the influence of diverting flood surge from one side to another $[8,9]$.

Flood risk is defined as the probability of loss as a function of three parameters: flood hazard, vulnerability, and exposure [10, 11]. Floodplain ecosystems are dynamic systems, which rely on the regularly occurring floods, alternating living conditions for its species and leading to high diversity $[12,13]$. The floodwaters also bring nutrient-rich sediment, which covers the flooded ground making it a particularly fertile system for quick establishment of species after disturbance $[14,15]$. However, worldwide river alterations lead to a degradation of floodplain ecosystems such as alluvial forests, as one of the most diverse ecosystems of the world [16]. Floodplain ecosystems belong to the most threatened ecosystems, having lost most of their functions such as water purification or flood protection because rivers are dyked, straightened, and under intense agricultural use $[17,18]$. The study areas location is Taunsa Barrage Wildlife Sanctuary, Kot Mithan - Chachran Site, and the Indus Dolphin Game Reserve (Guddu Barrage to Sukkur Barrage), Punjab, Pakistan. Indus Dolphin is endangered species, which makes this area very important from a biodiversity perspective. The area starts right from the upstream of Taunsa Barrage, passes through the confluence point of head Panjnad and then Guddu Barrage, and ends at the downstream of Sukkur Barrage. Leiah, Muzaffargarh, Dera Ghazi (D. G.) Khan, Multan, RajanPur, Rahim Yar Khan, Sukkur, Ghotki, Kashmor, Shikarpur, Larkana, and Khairpur are the districts that lie in the study area. These districts faced heavy damages due to floods in 2010 and are almost every year hit by floods [19]. This region of Indus River from Taunsa to Sukkur is not only important from a river ecology point of view but also provides an efficient network of canals that serve as a driver of high yield in the agriculture industry. Furthermore, rich wildlife and forest ecosystems enhance biodiversity's importance [20]. The main crops produced in this area are wheat, rice, sugar cane, and cotton. Mangoes, banana, and dates orchards are also found abundantly because of a suitable climate.

The objective of this study is to develop multithematic criteria and calculate the flood risk by following an assessment-based approach. The analysis was conducted to prepare a plan for flood disaster risk management by assessing the risk of floods as a function of inundated areas for economic, social, and environmental losses distributed spatially.

\section{Materials and Methods}

For the assessment of the risk, 10 community sites were selected in three biodiversity zones in the areas which are (i) Taunsa Barrage Wildlife Sanctuary in
Muzaffargarh district (ii) Kot Mithan \& Chacharan Site in Rajanpur district, and (iii) Indus Dolphin Reserve (Region between Guddu and Sukkur barrages with a $10 \mathrm{~km}$ buffer) (Fig 1). Flood risk was assessed under three criteria i.e.; Economic/Monetary, Social and, Environmental (Table 1) [21-23]. Historic flood extents were extracted from primary and secondary sources using reports and multi-temporal satellitebased products taking water flow as reference for low, medium, and high floods. Historic flooding events acted as benchmarks for future risk assessment analysis. Flood risk zones were subjected to the grid base calculation using multi-criteria evaluation and numerical results of flood risk were mapped in the spatial domain for all three selected sites. To estimate the build-up structure risk, human settlement events in a buffer region of project sites Taunsa Wildlife Sanctuary and Kot Mithan were extracted from high-resolution satellite imagery.

Multiple datasets from USGS (https://www.usgs. gov/) like SRTM DEM (Digital Elevation Model), and Landsat 8 (satellite images) were used to develop multi-temporal river geometry and terrain profile. Topographic sheets of scale ranging from 1:250,000 to $1: 50,000$ were requested from the Soil Survey of Pakistan (SoP) and features like river path, protection bund, roads, railway lines, etc. were extracted. The geological profile of the study area was mapped through SoP sheets. Yearly water discharge data for the last 55 years for maximum and minimum (Below Taunsa Barrage) was provided by the Punjab Irrigation Department from 1958 to 2013. It was observed from water flow tables that maximum discharge usually occurs from July to September which was used to set initial boundary conditions for inundation modeling $[24,25]$. DEM was cleaned using a fill tool and sinks were removed. Further, it was resampled to $30 \mathrm{~m}$ to be used in grid-based calculations in line with datasets from Landsat of $30 \mathrm{~m}$ resolution. A low pass filter was applied to improve the autocorrelation between the pixels [26]. Object-based image analysis techniques were used to extract land cover/land use thematic layers from satellite images. The classified images provided the information regarding the surface of the earth that was further used to define the manning's $\mathrm{n}$ value (Roughness coefficient) against each land-use class [27]. The roughness factor is a very important parameter to describe the water flow on the ground inundation modeling using HEC-RAS [28]. The third component of the River network geometry is based on the vector layers of the topographic data sets like river centerline, flow paths, riverbanks, river over bank bridges, etc. River and its floodplain cross-sectional profiles are the key inputs to model the water flow inside and outside of the riverbanks. Gradually varied flow was characterized by minor changes in water depth and velocity from the cross-section area. The primary procedure used by HEC-RAS to compute water surface profiles assumes a steady flow scenario, which was adapted for this study. Flood inundated areas were delineated by integrating 

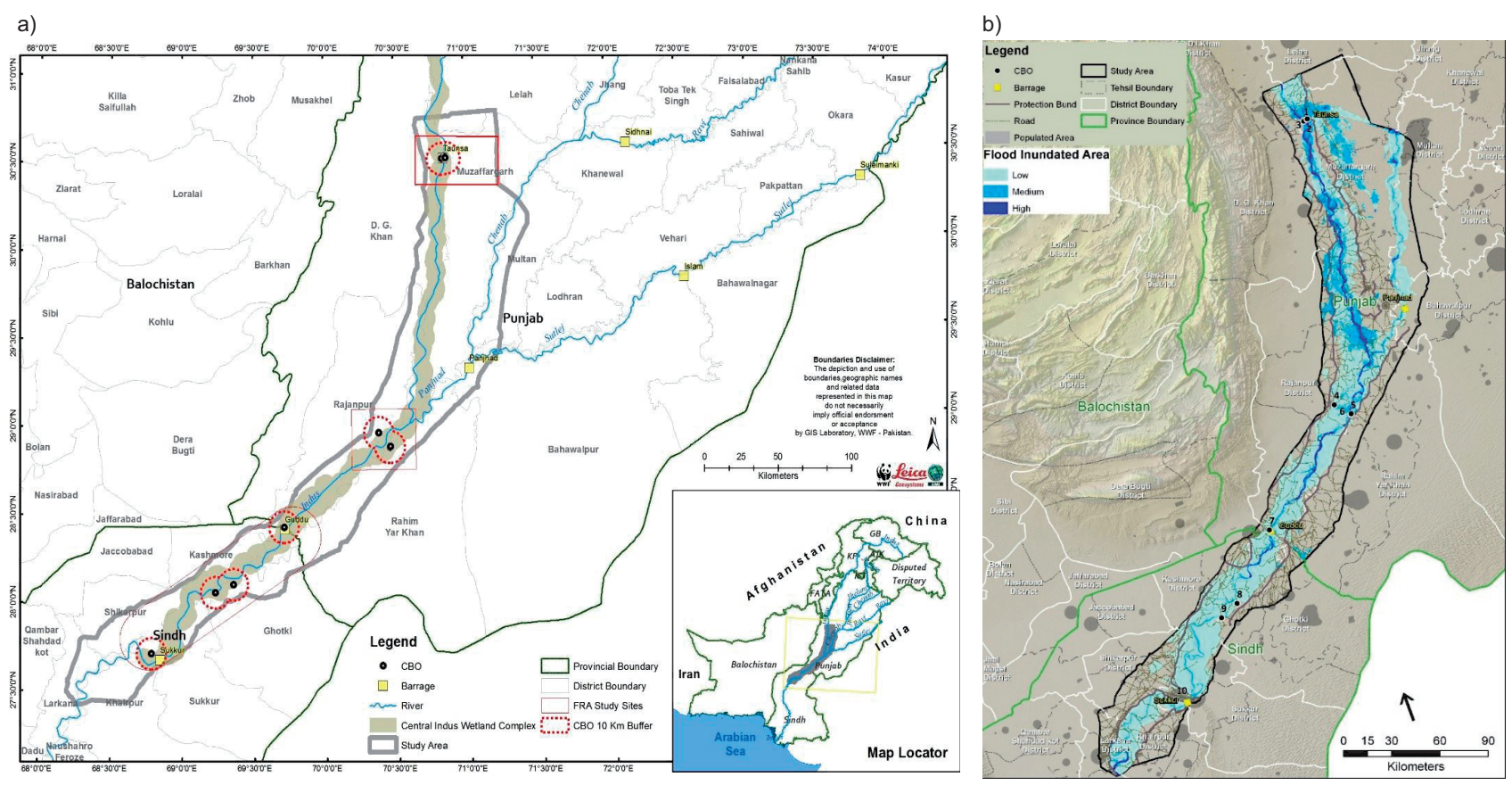

Fig 1. a) Study area map for flood risk assessment-CIWC (Central Indus Wetlands Complex), b) Outputs of Inundation modeling from Hec-GeoRAS and HECRAS.

ArcGIS utility i.e. HEC-GeoRAS with HEC-RAS [24]. Hec-GeoRas requires the cross-sectional cut lines besides the DEM, land use, and topographic layers. The geometry of the river that consists of riverbanks, bridges, flow paths, and river cutlines were identified. The total length of the river in the study area $(520 \mathrm{~km}$ approximately) was divided into $94 \mathrm{x}$ cutlines. Before exporting the river network geometry, it is necessary to assign the manning's $n$ value and the elevation to each cross-section (xscutlines) [29, 30].

Population data was acquired from published gridded population products under Demobase Pakistan by the United States Census Bureau - International Programs [31]. The spatial distribution of the affected population is calculated by using a subset of data over risk zones. An intersection of population data with flood risk zones gives the affected population under different probability scenarios. As "social hot spots" the locations of hospitals, schools, markets, banks, bus/train stations, and picnic points were attributed to major cities. For reasons of simplicity it was suggested that each of the hot spots has the same vulnerability, no matter the size of a hospital or school or whether it is a primary or secondary school. Such differentiation would lead to a more precise evaluation of social hot spots as a layer overlay of major cities on risk zones (Fig. 2 and S1). To assess the risk of environmental elements the flood risk criteria was evaluated against erosion and accretion of pollutants and their relation to different risk zones [32-34]. Forest area was also mapped against risk zones to point the risk threats of different levels to a forest cover. To develop erosion and accretion an overlay analysis of two datasets was done on Indus River (Indus River in 2000 and 2013). Forest cover layers were developed from SoP's Topographic maps and LCLU (landcover and land use) data developed from satellite images for the year 2013.

It was noticed from the past flood risk assessment studies that the focus was put on economic risks and it is unfortunately a general practice in Pakistan that social and environmental risks are not considered in such detail. The list of risk categories and criteria was also kept simple and minimal to make its applicability doable [33] (Table 1). To standardize the evaluation, process a vector grid of size $100 \mathrm{~m}$ by $100 \mathrm{~m}$ (equivalent to 1 hectare) cell size was developed, and the cost of each grid element was valued. LCLU for the year 2014 was used to extract the land under agriculture practices and crop damages per acre. Major damage in 2010 floods was recorded against rice, cotton, and sugarcane crops. Average damages were estimated for a mature crop and expenditure values were taken from communities earning a livelihood from the land adjoining the river. All the values were calculated as the total cost of underlying build-up structures, agriculture loss, road, canal, and protection bund as annual average damage of assets falling under a certain risk zone. The probability factor against each zone was applied and damage per unit area $\left(\mathrm{PKR} / \mathrm{m}^{2}\right)$ was calculated using the flood risk estimation equation (Flood Risk $=$ Flood Hazard $\times$ Vulnerability $\times$ Amount) [4]. A risk map was prepared for all three sites for the flood risk management plan (Fig. 2). 


\begin{tabular}{|c|c|c|c|c|c|c|c|c|}
\hline 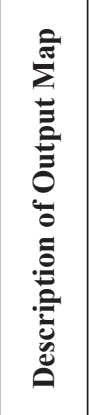 & \multicolumn{3}{|c|}{ 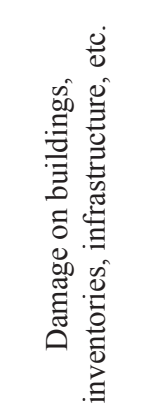 } & 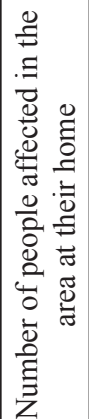 & 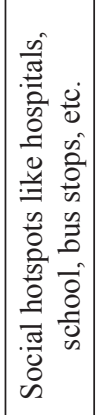 & 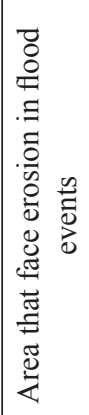 & 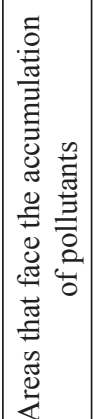 & 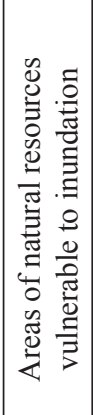 \\
\hline 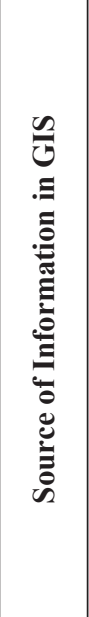 & 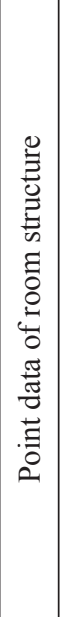 & 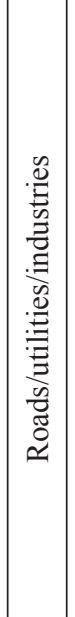 & 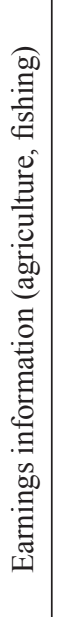 & 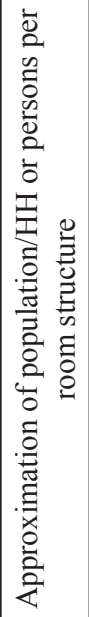 & 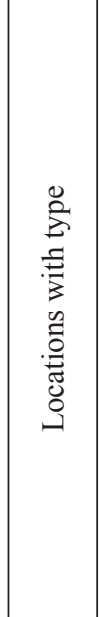 & 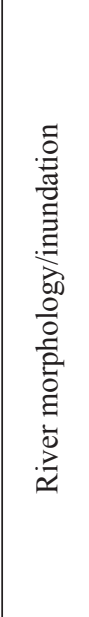 & 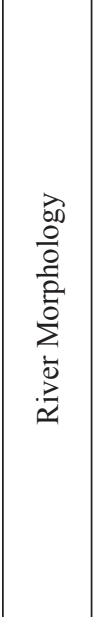 & 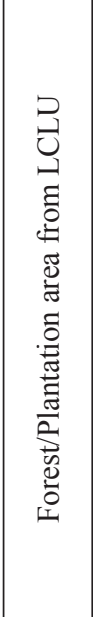 \\
\hline 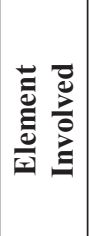 & $\mid$\begin{tabular}{l|}
$\frac{n}{0}$ \\
0 \\
0 \\
0 \\
0 \\
0 \\
0 \\
\end{tabular} & 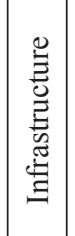 & 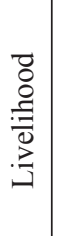 & 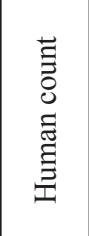 & 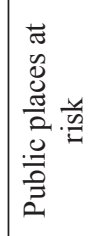 & 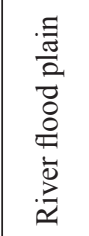 & 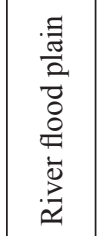 & 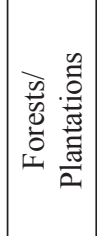 \\
\hline 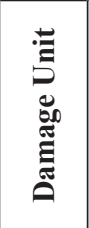 & & 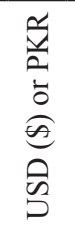 & & 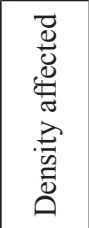 & 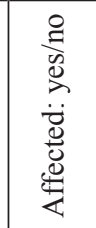 & 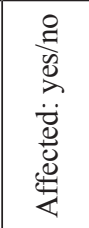 & 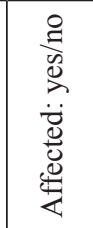 & 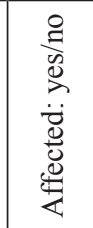 \\
\hline 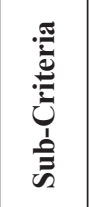 & 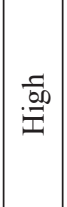 & 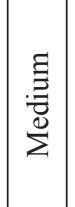 & $\begin{array}{l}z \\
0 \\
⿶ \\
\mid\end{array}$ & 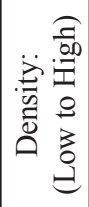 & & 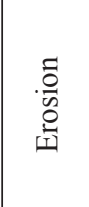 & 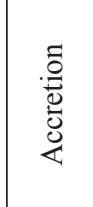 & 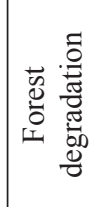 \\
\hline & & 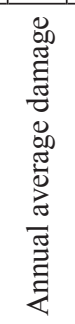 & & 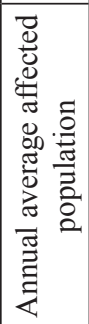 & 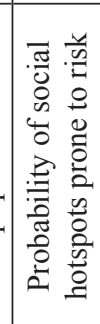 & & 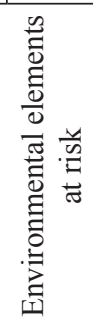 & \\
\hline 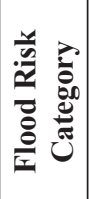 & & 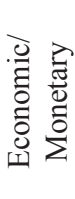 & & & & & 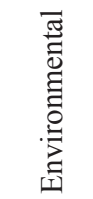 & \\
\hline$\dot{\vec{n}}$ & & - & & & $\mathrm{N}$ & & $m$ & \\
\hline
\end{tabular}

\section{Results and Discussion}

\section{Risk Assessment}

Although Indus river discharge varies widely, however, there was huge peak ( 1.1 million cusecs of water were passing through the Taunsa Barrage) in 2010 flood. During the 2010 Flood, almost 4,200 small and large villages/towns were inundated. Out of 4,200, approximately 1,750 villages/towns are on the right bank and the remaining 2,450 are on the left bank which highlights high economic and financial risk. The main cities which were impacted by the flood were Daira Din Panah, Kot Addu, Ehsan Pur, Makwal Kalan, Alipur, Seetpur, Liaqat Pur and Jatoi (in Muzaffargarh District), Mithan Kot, Umar Kot, Jam Pur and Rajan Pur city (in RajanPur District), Chacharan, Rukun Pur, Puli Pahuran (in Rahim Yar Khan District) Guddu, Kashmor, (in Kashmor District) Ghotki, Qadirpur, Runwati, Gamro (in Ghotki District) Pano aqal, Sukkur, Pirjo Goth, Pirya Loi (in Sukkur District). The overall area covers 2,235.42 $\mathrm{km}^{2}$ and almost $450 \mathrm{~km}$ long stretch of River Indus. Both banks of the river are populated, and fishing, agriculture, and livestock are sources of income.

Based on Flood Inundation Modeling out of the total study area $22,335.42 \mathrm{~km}^{2}, 10,187.82 \mathrm{~km}^{2}$ is prone to flood and this flood was further categorized in Low Medium and High Intensity based on the depth of inundation (Table 2 and Fig. 2). Major Tehsils that have been badly affected by the flood were Taunsa, Liaqatpur, Jatoi, AliPur, JamPur, Kot Addu, RajanPur, Rojhan, Sadaqabad, Khanpur, Kashmor, Kandhkot, Pano Aqil. Larkana and Gambat Taluka and these Taluka/Tehsils receive Medium to High-Intensity floods. Muzaffargarh is the most prone district in the study area which receives the most severe flood with more than half of its land underwater. D. G. Khan, Rajanpur, Kashmor, Sukkur, and Shikarpur districts which suffer the greater land and economical loss (Table 2 and Fig. 2). The remaining districts in the total study area did not bear the same brunt but suffered destruction and created a hazard for the community that stands on inundated areas; their livestock and agriculture land were severely impacted. In communities located very close to Indus river, most of them are prone to high and medium-level floods.

Based on risk assessment criteria, the statistical details for all the three site for annual average damage is given in Table 2 and 3. It is evident from the numbers from Table 2 that in high-risk zones of all three sites Taunsa WS, Kot Mithan-Chachran site, and Indus Dolphin Reserve, the maximum value of annual average damage ranges up to $211,1,179$, and $5,907 \mathrm{PKR} / \mathrm{m}^{2}$ respectively. These values are dependent on buildup structures and agricultural assets and clearly show that areas in Indus Dolphin reserve are at a high-risk level than other two. The reason for this high range is the cities in the vicinity of the River Indus and that is Sukkur and Rohri. Same is case with Kot Mithan and 


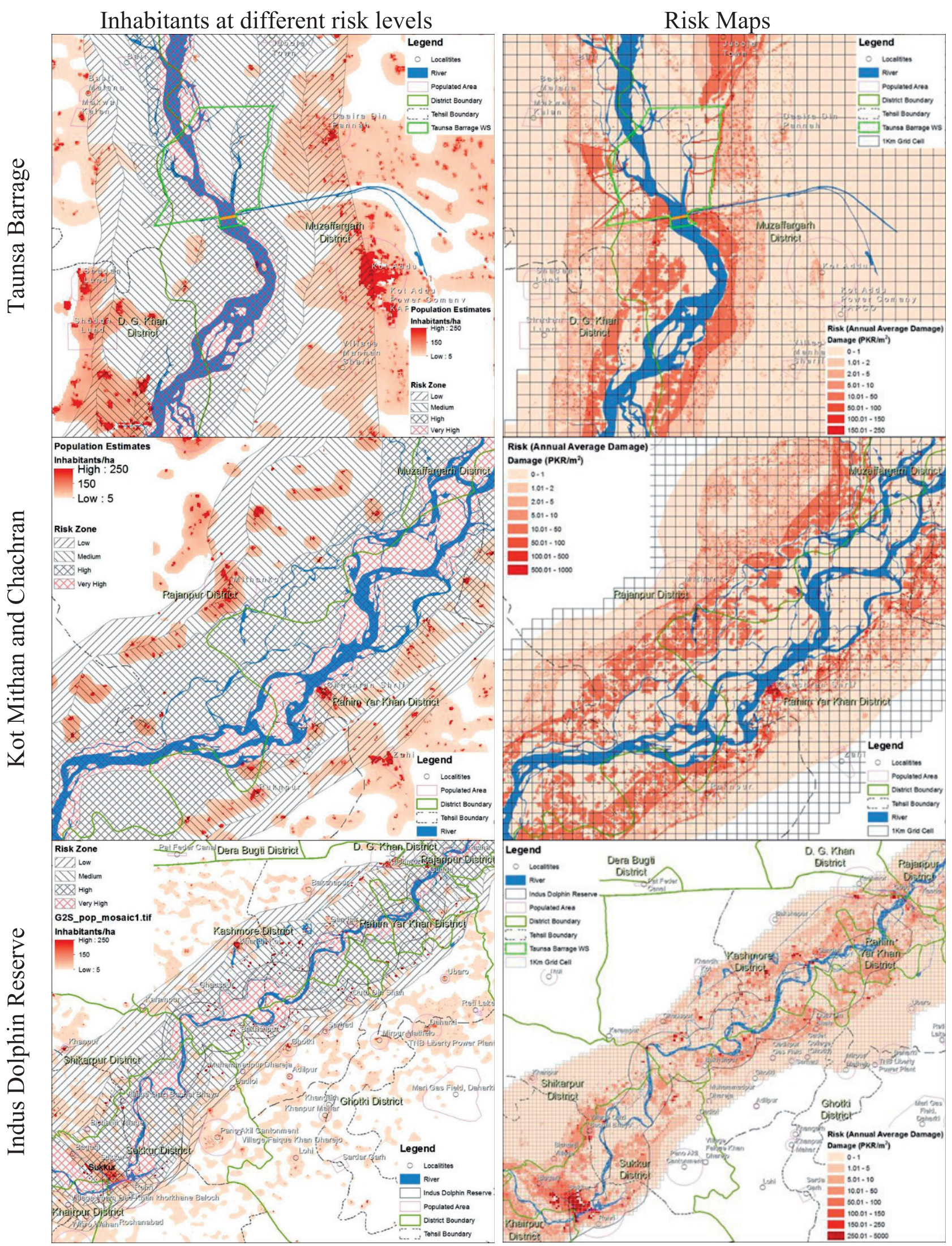

Fig. 2. Inhabitants at different risk levels and risk maps for annual average damage showing value in $\mathrm{PKR} / \mathrm{m}^{2}$ in the study area (Taunsa Barrage, Kot Mithan, and Chachran, and Indus Dolphin Reserve). 
Table 2. Estimated economic risk with the population size of the study area.

\begin{tabular}{|c|c|c|c|c|c|c|c|c|c|c|c|}
\hline \multirow{2}{*}{ Site } & \multirow{2}{*}{ Risk Zone } & \multirow{2}{*}{$\begin{array}{l}\text { Probability } \\
\text { Index }\end{array}$} & \multirow{2}{*}{$\begin{array}{c}\text { Assets } \\
\text { Area } \\
\text { (ha) }\end{array}$} & \multirow{2}{*}{$\begin{array}{c}\text { Area } \\
(\%)\end{array}$} & \multicolumn{4}{|c|}{ Damage (PKR/m²) } & \multirow{2}{*}{$\begin{array}{l}\text { Estimated } \\
\text { Population }\end{array}$} & \multirow{2}{*}{$\begin{array}{c}\text { Zone } \\
\text { Area } \\
\text { (ha) }\end{array}$} & \multirow{2}{*}{$\begin{array}{c}\text { Population } \\
\text { Density } \\
\text { (No./ha) }\end{array}$} \\
\hline & & & & & Min & Max & $\begin{array}{l}\text { Data } \\
\text { Mean }\end{array}$ & $\begin{array}{c}\text { Range } \\
\text { Average }\end{array}$ & & & \\
\hline \multirow{6}{*}{$\begin{array}{c}\text { Taunsa } \\
\text { Barrage } \\
\text { WS }\end{array}$} & Very High & 1 & 9,361 & 6 & 1 & 123 & 1.6 & 62 & 2,560 & 136 & 18.8 \\
\hline & High & 0.8 & 16,068 & 10 & 1 & 211 & 10.2 & 106.1 & 20,049 & 780 & 25.7 \\
\hline & Medium & 0.1 & 22,594 & 13 & 1 & 63 & 1.8 & 32.1 & 75,144 & 4,967 & 15.1 \\
\hline & Low & 0.01 & 20,407 & 12 & 1 & 8 & 0.3 & 4.5 & 173,806 & 12,710 & 13.7 \\
\hline & No Risk & 0 & 100,255 & 59 & 0 & 0 & 0 & 0 & 350,904 & 27,692 & 12.7 \\
\hline & \multicolumn{2}{|c|}{ Total } & 168,685 & 100 & - & - & - & - & 622,463 & 46,285 & 13.4 \\
\hline \multirow{6}{*}{$\begin{array}{c}\text { Kot Mithan } \\
\text { /Chachran } \\
\text { Site }\end{array}$} & Very High & 1 & 27,423 & 20 & 1 & 943 & 1.6 & 472 & 3,604 & 227 & 15.9 \\
\hline & High & 0.8 & 47,505 & 34 & 1 & 1,179 & 10.8 & 590 & 51,204 & 3,374 & 15.2 \\
\hline & Medium & 0.1 & 28,627 & 21 & 1 & 831 & 25.4 & 416 & 149,798 & 10,555 & 14.2 \\
\hline & Low & 0.01 & 21,279 & 15 & 1 & 1,495 & 27.1 & 748 & 78,933 & 5,716 & 13.8 \\
\hline & No Risk & 0 & 14,479 & 10 & 0 & 0 & 0 & 0 & 91,556 & 7,031 & 13 \\
\hline & \multicolumn{2}{|c|}{ Total } & 139,313 & 100 & - & - & - & - & 375,095 & 26,903 & 13.9 \\
\hline \multirow{6}{*}{$\begin{array}{c}\text { Indus } \\
\text { Dolphin } \\
\text { Reserve }\end{array}$} & Very High & 1 & 88,050 & 14 & 1 & 8,550 & 15 & $4,275.50$ & 44,364 & 2,031 & 21.8 \\
\hline & High & 0.8 & 175,825 & 29 & 1 & 5,907 & 30.3 & $2,954.10$ & 537,372 & 16,540 & 32.5 \\
\hline & Medium & 0.1 & 105,325 & 17 & 1 & 587 & 4.1 & 294.2 & 391,033 & 25,534 & 15.3 \\
\hline & Low & 0.01 & 145,800 & 24 & 1 & 35 & 0.3 & 18.1 & 836,061 & 51,566 & 16.2 \\
\hline & No Risk & 0 & 94,450 & 15 & 0 & 0 & 0 & 0 & 419,552 & 31,066 & 13.5 \\
\hline & \multicolumn{2}{|c|}{ Total } & 609,450 & 100 & - & - & - & - & $2,228,382$ & 126,737 & 17.6 \\
\hline
\end{tabular}

Table 3. Environmental risk for the CBO $10 \mathrm{~km}$ Buffer areas.

\begin{tabular}{|c|c|c|c|c|c|c|c|c|c|}
\hline \multirow{2}{*}{$\begin{array}{c}\text { Sr. } \\
\text { No. }\end{array}$} & $\begin{array}{c}\text { Study Site } \\
\mathbf{( 1 0} \text { km Buffer) }\end{array}$ & \multicolumn{3}{|c|}{ River Change Area (ha) } & \multicolumn{5}{c|}{ Forest Area (ha) vs Risk zone } \\
\cline { 3 - 10 } & Erosion & Accretion & No Change & $\begin{array}{c}\text { Low } \\
\text { Risk }\end{array}$ & $\begin{array}{c}\text { Medium } \\
\text { Risk }\end{array}$ & $\begin{array}{c}\text { High } \\
\text { Risk }\end{array}$ & $\begin{array}{c}\text { Very High } \\
\text { Risk }\end{array}$ & Total \\
\hline 1 & Taunsa Barrage Site & $3,048.67$ & $1,859.14$ & $2,309.18$ & 0.00 & 279.69 & 212.82 & 252.21 & 744.72 \\
\hline 2 & Kot Mithan-Chachran Site & $3,679.50$ & $1,982.18$ & $1,379.99$ & 86.19 & $1,575.01$ & 159.07 & 111.88 & $1,932.14$ \\
\hline 3 & Guddu Barrage Site & $3,850.59$ & $1,304.28$ & $1,522.45$ & 0.00 & 0.00 & 0.00 & 75.65 & 75.65 \\
\hline 4 & Ghotki Site & $4,063.16$ & $5,107.20$ & $1,706.12$ & 15.66 & $3,972.54$ & $2,565.14$ & $3,999.56$ & $10,552.90$ \\
\hline 5 & Sukkur Barrage Site & $1,692.62$ & $1,275.81$ & $1,036.80$ & 0.00 & 25.69 & 553.91 & $3,303.31$ & $3,882.91$ \\
\hline
\end{tabular}

Chachran Site. Taunsa Barrage and Indus Dolphin reserve have high ratios of population to risk zone area as compared to Kot Mithan- Chachran site in High and Very High-Risk zones. Indus Dolphin Reserve has a high environmental risk in terms of erosion and to various forest categories. More than fifty percent of the forest is lying in very high-risk zones.

\section{Risk Treatment and Strategies}

Risk treatment encircles the management practices for assets, people, and money through direct and indirect methods. This requires a lasting learning process at the local, regional, national, and international levels. Risk treatment can be direct and indirect.

Direct risk management involves deciding on a scenario by scenario basis on what measures should be taken. Several options are available depending on what is allowed by the risk management method. Reliance on a risk scenario knowledge base in which appropriate safety measures are referenced and which allows an evaluation of their effects in terms of reducing the level of risks. The most interesting option is the risk scenario knowledge base in which pertinent safety measures are referenced for each scenario and which allows an evaluation of the effects of these measures in terms 

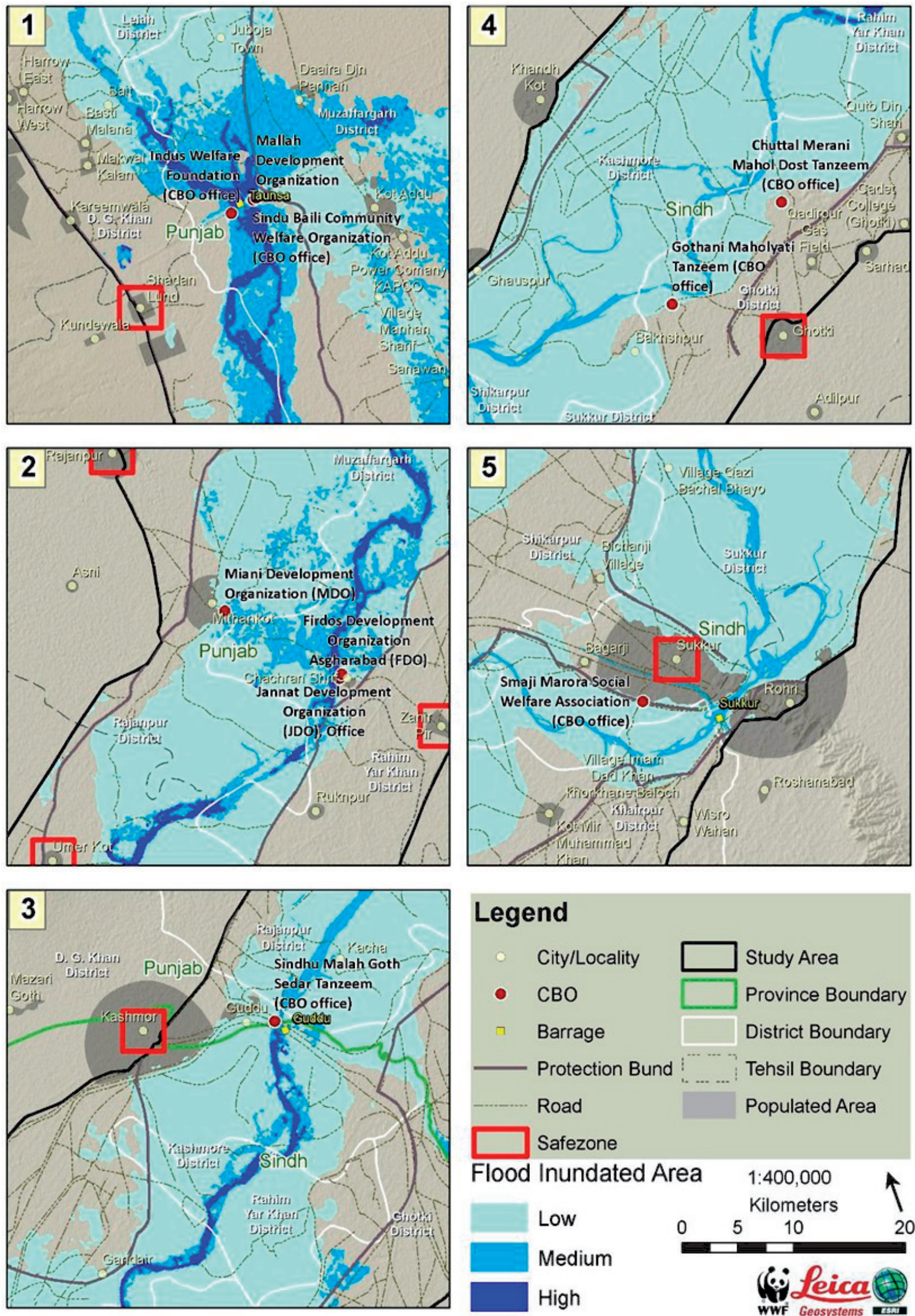

Fig. 3. Identified safe zones (1) Taunsa Barrage WS (2) Kot Mithan-Chachran site (3) Guddu Barrage (4) Ghotki Site (5) Sukkur Site. 
of reducing the level of risk. This directly involves the analysis of different elements at risk and their quantification [21]. In our case, Kot Mithan- Chachran and Indus Dolphin reserve sites show a high economic loss, if flooded in high and very high-risk zones. Policy level measures are required to reduce this risk by efficiently using flood-prone lands for agriculture. In some circumstances, the risk is completely defined, it is possible for the activity, project, and process managers to directly manage the solutions to be implemented and this often proves to be economical. Disaster Risk Reduction plans are examples of this. A disaster response plan designed by Provincial Disaster Management Authority (PDMA) articulate the strategies to tackle flood disaster after the event occurs but the impacts of disaster can be reduced by executing strengthening projects and activities to enhance resilience to flood events in upstream and associated areas of the river [35]. Flood risk zonation maps can be an initial point to design such project. Strengthen schemes of protection of infrastructure and increasing the capacity of pond areas is advised to reduce the flooding risk. The flood risk of seepage can be reduced by developing Sem Nullahs along the protection bunds. Plantation schemes on the protection bunds can reduce the bund breaching threat. Community resettlement to a safe zone can reduce or almost eliminate the life losses during floods [36, 37]. Such activities must be carried out in the pre-flood risk management phase.

In the Indirect approach, the risk is reduced by reducing the vulnerabilities defined on a threat basis. Following are different schemes that can play a major role to reduce flood impacts in a long-term arrangement.

- Capacity building of the local communities.

- Deployment of early warning systems.

- Identify the safe zones near the local communities.

- Evacuation strategy during the flood.

- Strengthening and monitoring of the protection bunds.

- Identify the communities which lie within the river and protection bund.

- Flood plain harvesting.

People associated with agriculture and livestock occupation are at high risk of flood damages as compared to fishing. Thus, awareness programs for such communities are highly advised to tackle and reduce the flood risk [38]. During flood, the communities of these areas move to protection bunds or barrages, which is highly risky itself. A better plan could be the identification of flood-safe zones and develop them to fully accommodate the communities residing in the high and very high-risk zone of the flood [39-42]. Sites identified as safe zone for communities (i.e. Chuttal Merani Mahol Dost Tanzeem and Gothani Maholyati Tanzeem) in Guddu downstream area, are Ghotki City, Khan Garh, Meerpur Mathelo. For Communities in Kot Mithan and Chachran area, safe zones are Rajanpur City Umar Kot and Zahir Pir city. Railway Station Kot Mithan is also an elevated safe zone if a very short time for relocation is available. For the Taunsa Barrage site, Shadan Lund is located in flood safe zones. For Sukkur and Rohri the cities are at high risk under distance from the river criterion but have been observed as safe zone under very high flood 2010 so Sukkur City and Rohri City can be considered relatively safe zones (Fig. 3).

\section{Conclusions}

Flood risk can be reduced by redesigning the existing land use of flood plains in accordance with area's natural ecology. The engineering and bioengineering approaches will ultimately reduce the likelihood of the occurrence of the flood [39, 43, 44, 45]. The Command, Control, and Communication (3C) Center serves as the hub of coordination for the Government response to a disaster. All the relevant Government departments contribute through 3C to plan and coordinate the response activities. The main responsibilities of $3 \mathrm{C}$ are to receive early warnings and issue information to the public, media, ministries, departments, and humanitarian response agencies. The 3C coordinates relief and early recovery work in the post-disaster scenario [46, 47]. The $3 \mathrm{C}$ oversees the deployment of evacuation, medical, search and rescue teams in the affected area. Continuous monitoring and feedback to $3 \mathrm{C}$ are advised for efficient deliverance of pre-and post-flood support to fight the disaster risks. Government and communities can contribute to fight flood risk and take measures as suggested in the following [48];

- Improvement of embankment, barrages, bridges, roads, railways, forests, plantation of trees, etc [49].

- Upraising and construction of dams, lakes, emergency canals, new embankments [50].

- Consolidated flood diversion plan at various upstream locations [51].

- Evacuation plan, alternate living places through community participation, etc [52].

- Community awareness, development, and preparedness plans/strategies regarding floods, river/ embankment erosions/breaching, forest cutting, illegal living/agricultural activities inside river plain or flood red zones, etc. [53].

- Flood extent zonation [54].

- Installation of utilities, housing, industry, and other infrastructure according to flood extent zones [55].

Above all flood causes major damages and we need to be flood resilient to cater to the impacts and take benefits from the flood water at its best [56]. This is only possible when we make wise decisions based on facts and figures [57].

\section{Acknowledgment}

We thank the Soil Survey of Pakistan, Punjab Irrigation Department, United States Census Bureau, 
and WWF-Pakistan for providing different types of datasets, and field support to carry out the study. We also thank anonymous reviewers for reviewing the manuscript.

\section{Conflict of Interest}

The authors declare no conflict of interest.

\section{References}

1. PAULIKAS M., RAHMAN M.A. Temporal Assessment of Flooding Fatalities in Pakistan (1950-2012). J Flood Risk Manag. 8 (1), 62, 2015.

2. LIU T., TSUDA M., IWAMI Y. A Study on Flood Forecasting in the Upper Indus Basin Considering Snow and Glacier Meltwater. J Disaster Res. 12 (4), 793, 2017.

3. WIJNGAARD R.R., LUTZ A.F., NEPAL S., KHANAL S., PRADHANANGA S., SHRESTHA A.B., IMMERZEEL W. W. Future Changes in Hydro-Climatic Extremes in the Upper Indus, Ganges, and Brahmaputra River Basins. PloS One. 12 (12), e0190224, 2017.

4. WARD P.J., JONGMAN B., WEILAND F.S., BOUWMAN A., VAN BEEK R., BIERKENS M.F., LIGTVOET W., WINSEMIUS H.C. Assessing Flood Risk at the Global Scale: Model Setup, Results, and Sensitivity. Environ Res Lett. 8 (4), 044019, 2013.

5. RIND M.A., ANSARI K., SAHER R., SHAKYA S., AHMAD S. 2D Hydrodynamic Model for Flood Vulnerability Assessment of Lower Indus River Basin, Pakistan. In World Environmental and Water Resources Congress 2018: Watershed Management, Irrigation and Drainage, and Water Resources Planning and ManagementSelected Papers from the World Environmental and Water Resources Congress 2018, 2018.

6. MAHMOOD S., RAHMAN A.U. Flash flood susceptibility modeling using geo-morphometric and hydrological approaches in Panjkora Basin, Eastern Hindu Kush, Pakistan. Environ. Earth Sci., 1;78(1):43, 2019.

7. MEMON A.A. Devastation of the Indus River Delta. In Impacts of global climate change, 1, 2005.

8. GIORDANO M., GIORDANO M., WOLF A. The Geography of Water Conflict and Cooperation: Internal Pressures and International Manifestations. Geogr J. 168 (4), 293, 2002,

9. MCCRACKEN M., PETERS L.E., WOLF A.T. Megatrends in shared waters in 2030 and beyond. In Assessing global water megatrends. Springer, 105, 2018.

10. KOKS E.E., JONGMAN B., HUSBY T.G., BOTZEN W.J. Combining hazard, exposure and social vulnerability to provide lessons for flood risk management. Environ Sci Policy, 47, 42, 2015

11. KOKS E.E., JONGMAN B., HUSBY T.G., BOTZEN W.J. Combining hazard, exposure and social vulnerability to provide lessons for flood risk management. Environ Sci Policy, 1 (47), 42, 2015.

12. MAITI S. Defining a Flood Risk Assessment Procedure Using Community Based Approach with Integration of Remote Sensing and GIS, Based on The 2003 Orissa Flood, ITC, 2007.
13. BAYLEY P.B. Understanding Large River: Floodplain Ecosystems. BioSci. 45 (3), 153, 1995.

14. FRESCO L.O., KROONENBERG S.B. Time and Spatial Scales in Ecological Sustainability. Land Use Pol. 9 (3), $155,1992$.

15. M. ABDELDAYEM O., ELDAGHAR O., K. MOSTAFA M., M HABASHY M., HASSAN A.A., MAHMOUD H., M. MORSY K., ABDELRADY A., PETERS RW. Mitigation plan and water harvesting of flashflood in arid rural communities using modelling approach: A case study in Afouna village, Egypt. Water, 12 (9), 2565, 2020.

16. STAGL J., HATTERMANN F. Impacts of Climate Change on Riverine Ecosystems: Alterations of Ecologically Relevant Flow Dynamics in the Danube River and Its Major Tributaries. Water. 8 (12), 566, 2016.

17. PRINGLE C., VELLIDIS G., HELIOTIS F., BANDACU D., CRISTOFOR S. Environmental Problems of the Danube Delta. Ekistics. 62 (370-372), 140, 1995.

18. BARREDO J.I. Major Flood Disasters in Europe: 19502005. Nat Hazards. 42 (1), 125, 2007.

19. VITERBO F., VON HARDENBERG J., PROVENZALE A., MOLINI L., PARODI A., SY O.O., TANELLI S. HighResolution Simulations of the 2010 Pakistan Flood Event: Sensitivity to Parameterizations and Initialization Time. J Hydrometeorol. 17 (4), 1147, 2016.

20. SALIK K.M., HASHMI M.Z.-R., ISHFAQ S., OTHERS. Environmental Flow Requirements and Impacts of Climate Change-Induced River Flow Changes on Ecology of the Indus Delta, Pakistan. Reg Stud Mar Sci. 7, 185, 2016.

21. LYU H.-M., SUN W.-J., SHEN S.-L., ARULRAJAH A. Flood Risk Assessment in Metro Systems of Mega-Cities Using a GIS-Based Modeling Approach. Sci Total Environ. 626, 1012, 2018.

22. FEKETE A. Social Vulnerability (Re-)Assessment in Context to Natural Hazards: Review of the Usefulness of the Spatial Indicator Approach and Investigations of Validation Demands. Int J Disaster Risk Sci. 10 (2), 220, 2019.

23. ABDULRAZZAK M., ELFEKI A., KAMIS A., KASSAB M., ALAMRI N., CHAABANI A., NOOR K. Flash Flood Risk Assessment in Urban Arid Environment: Case Study of Taibah and Islamic Universities' Campuses, Medina, Kingdom of Saudi Arabia. Geomat Nat Hazards Risk, 10 (1), 780, 2019.

24. VOJTEK M., PETROSELLI A., VOJTEKOVÁ J., ASGHARINIA S. Flood Inundation Mapping in Small and Ungauged Basins: Sensitivity Analysis Using the EBA4SUB and HEC-RAS Modeling Approach. Hydrol. Res. 2019.

25. MAHMOOD S., RAHMAN A., SAJJAD A. Assessment of 2010 Flood Disaster Causes and Damages in District Muzaffargarh, Central Indus Basin, Pakistan. Environ Earth Sci. 78 (3), 63, 2019.

26. JUPP D.L., STRAHLER A.H., WOODCOCK C.E. Autocorrelation and Regularization in Digital Images. II. Simple Image Models. IEEE Trans. Geosci Remote Sens. 27 (3), 247, 1989.

27. KALYANAPU A.J., BURIAN S.J., MCPHERSON T.N. Effect of Land Use-Based Surface Roughness on Hydrologic Model Output. J Spat Hydrol. 9 (2), 2010.

28. VAN DER SANDE C., DE JONG S., DE ROO A. A Segmentation and Classification Approach of IKONOS-2 Imagery for Land Cover Mapping to Assist Flood Risk and Flood Damage Assessment. Int. J. Appl. Earth Obs. Geoinform. 4 (3), 217, 2003. 
29. GOODELL C., WARREN C. Flood Inundation Mapping Using HEC-RAS. Obras Proy. 18, 2006.

30. AFSHARI S., TAVAKOLY A.A., RAJIB M.A., ZHENG X., FOLLUM M.L., OMRANIAN E., FEKETE B.M. Comparison of New Generation Low-Complexity Flood Inundation Mapping Tools with a Hydrodynamic Model. J Hydrol. 556, 539, 2018.

31. AZAR D., ENGSTROM, R., GRAESSER J., COMENETZ J. Generation of Fine-Scale Population Layers Using Multi-Resolution Satellite Imagery and Geospatial Data. Remote Sens Environ. 130, 219, 2013.

32. MALILAY J., HEUMANN M., PERROTTA D., WOLKIN A.F., SCHNALL A.H., PODGORNIK M.N., CRUZ M.A., HORNEY J.A., ZANE D., ROISMAN R., OTHERS. The Role of Applied Epidemiology Methods in the Disaster Management Cycle. Am J Pub Health. 104 (11), 2092, 2014.

33. THALER T., HARTMANN T. Justice and flood risk management: reflecting on different approaches to distribute and allocate flood risk management in Europe. Nat Hazards, 1, 83 (1), 129, 2016.

34. MEYER V., SCHEUER S., HAASE D. A Multicriteria Approach for Flood Risk Mapping Exemplified at the Mulde River, Germany. Nat Hazards. 48 (1), 17, 2009.

35. DIEPERINK C., HEGGER D.T., BAKKER M.H., KUNDZEWICZ Z.W., GREEN C., DRIESSEN P.P. Recurrent governance challenges in the implementation and alignment of flood risk management strategies: a review. Water Resour. Manag., 1, 30 (13), 4467, 2016.

36. ANG Y.T., CHAN F.K., O'DONNELL E.C., GRIFFITHS J., LAU L., HIGGITT D.L., THORNE C.R. Aligning ancient and modern approaches to sustainable urban water management in China: Ningbo as a "Blue-Green City" in the "Sponge City" campaign. J. Flood Risk Manag, 11 (4), e12451, 2018.

37. KITA S.M. Urban vulnerability, disaster risk reduction and resettlement in Mzuzu city, Malawi. Int J Disast Risk Re, 1 (22), 158, 2017.

38. DAVIES T., BEAVEN S., CONRADSON D., DENSMORE A., GAILLARD J.C., JOHNSTON D., MILLEDGE D., OVEN K, PETLEY D., RIGG J., ROBINSON T. Towards disaster resilience: A scenario-based approach to coproducing and integrating hazard and risk knowledge. Int $\mathrm{J}$ Disast Risk Re, 1 (13), 242, 2015.

39. DEVKOTA R., BHATTARAI U., DEVKOTA L., MARASENI T.N. Assessing the past and adapting to future floods: a hydro-social analysis. Clim. Change, 163 (2), 1065, 2020

40. DAI L., VAN DOORN-HOEKVELD W.J., WANG R.Y., VAN RIJSWICK H.F. Dealing with distributional effects of flood risk management in China: compensation mechanisms in flood retention areas. Water Int., 4, 44 (5), 607, 2019.

41. VAN DOORN-HOEKVELD W.J., GOYTIA S.B., SUYKENS C., HOMEWOOD S., THUILLIER T., MANSON C., CHMIELEWSKI P.J., MATCZAK P., VAN RIJSWICK HF. Distributional effects of flood risk management - a cross-country comparison of preflood compensation. Ecol. Soc., 1, 21 (4), 2016.
42. MATHESWARAN K., ALAHACOON N., PANDEY R., AMARNATH G. Flood risk assessment in South Asia to prioritize flood index insurance applications in Bihar, India. Geomatics, Nat Hazards Risk, 25, 2018.

43. JONGMAN B. Effective adaptation to rising flood risk. Nat. commun, 29, 9 (1), 1, 2018.

44. HEGGER D.L., DRIESSEN P.P., BAKKER M.H. Evaluations of flood risk governance in terms of resilience, efficiency and legitimacy. In Flood Risk Management Strategies and Governance. Springer, Cham, 55, 2018.

45. ALEXANDER M., DOORN N., PRIEST S. Bridging the legitimacy gap-translating theory into practical signposts for legitimate flood risk governance. Reg. Environ. Change, 1, 18(2), 397, 2018.

46. DRIESSEN P.P., HEGGER D..L, KUNDZEWICZ Z.W., VAN RIJSWICK H.F., CRABBÉ A., LARRUE C., MATCZAK P., PETTERSSON M., PRIEST S., SUYKENS C., RAADGEVER G.T. Governance strategies for improving flood resilience in the face of climate change. Water, 10 (11), 1595, 2018.

47. SALMAN A.M., LI Y. Flood risk assessment, future trend modeling, and risk communication: a review of ongoing research. Nat Hazards Rev, 1, 19 (3), $04018011,2018$.

48. RAN J., NEDOVIC-BUDIC Z. Integrating spatial planning and flood risk management: A new conceptual framework for the spatially integrated policy infrastructure. Comput Environ Urban, 1, 57, 68, 2016.

49. AHMED M, RAHMAN M.M. Local Climate Change Governance and Making Climate Resilient Town: The Role of Local Authorities. Research \& Reviews: J. Archit. Des, 19, 2 (1, 2), 2020.

50. BAECHER G. B.History of Risk Analysis in Dam Safety. 2018.

51. DANG N.M., BABEL M.S., LUONG H.T. Evaluation of food risk parameters in the day river flood diversion area, Red River delta, Vietnam. Nat hazards, 1, 56 (1), 169, 2011.

52. NOONAN D.S., SADIQ A.A. Flood risk management: exploring the impacts of the community rating system program on poverty and income inequality. Risk Anal., 38 (3), 489, 2018.

53. RAADGEVER T., HEGGER D. editors. Flood risk management strategies and governance. Springer; 2018.

54. JAHANGIR M.H., REINEH S.M., ABOLGHASEMI M. Spatial predication of flood zonation mapping in Kan River Basin, Iran, using artificial neural network algorithm. Weather. Clim. Extremes, 1, 25, 100215, 2019.

55. FEKETE A., TZAVELLA K., BAUMHAUER R. Spatial exposure aspects contributing to vulnerability and resilience assessments of urban critical infrastructure in a flood and blackout context. Nat Hazards, 1, 86 (1), 151, 2017.

56. DEEN S. Pakistan 2010 Floods. Policy Gaps in Disaster Preparedness and Response. Int J Disas Risk Reduct. 12, 341, 2015.

57. SHAH A.A., YE J., ABID M., ULLAH R. Determinants of flood risk mitigation strategies at household level: a case of Khyber Pakhtunkhwa (KP) province, Pakistan. Nat Hazards, 1, 88 (1), 415, 2017. 


\section{Supplementary Material}

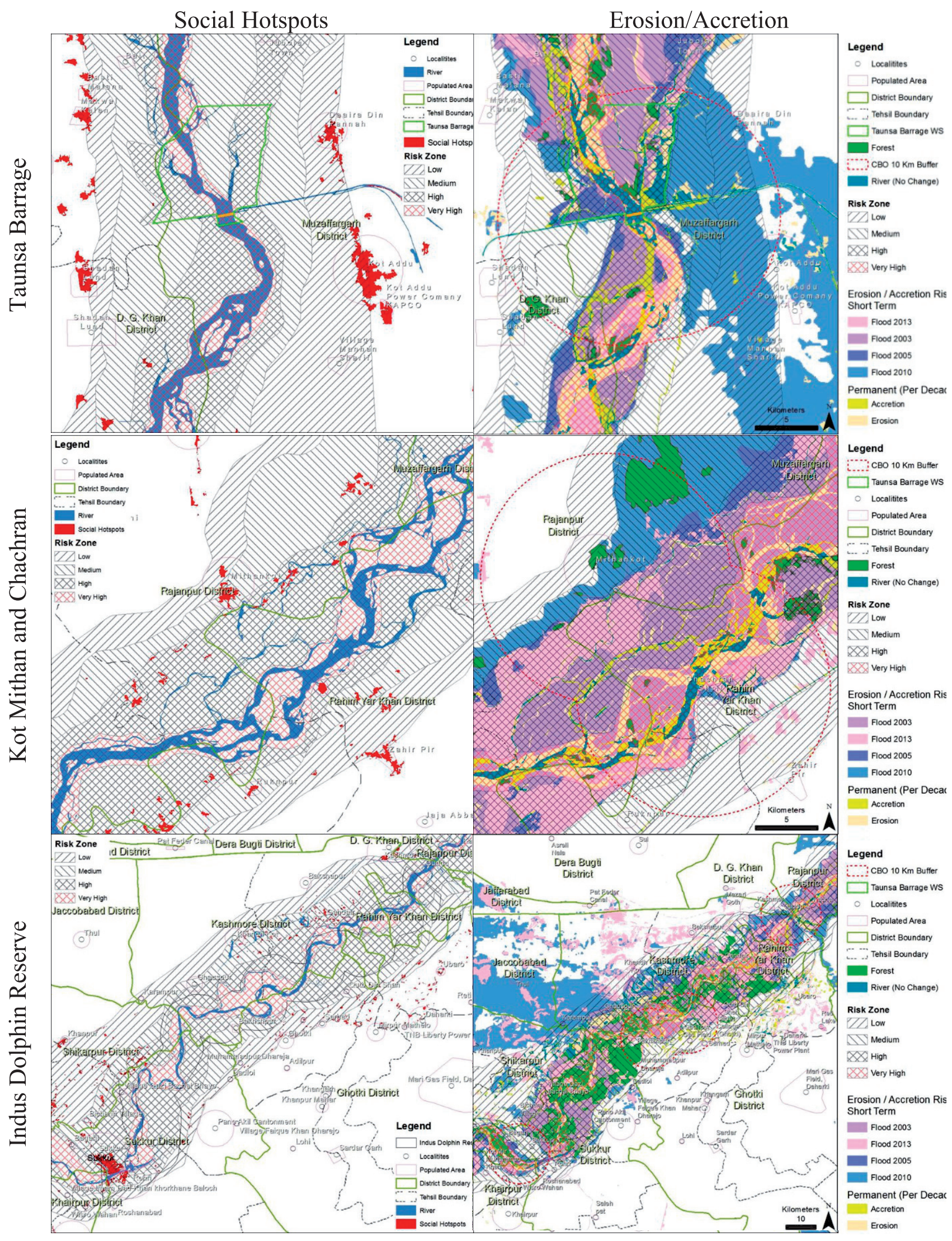

Fig. S1. Major cities and towns as social hotspots over different risk zones and Erosion/Accretion concerning different risk zones of study area (Taunsa Barrage, Kot Mithan, and Chachran, and Indus Dolphin Reserve). 